\title{
Effect of liming on the value of magnesium sulphate and two dolomitic limestones as magnesium sources for rye- grass
}

\author{
RAILI JOKINEN
}

University of Helsinki, Department of Agricultural Chemistry, SF-00710 Helsinki 71, Finland.

\begin{abstract}
The effect of liming on the fate of magnesium given as either magnesium sulphate ( $200 \mathrm{mg}$ $\mathrm{Mg} / 3.9 \mathrm{~kg}$ of soil) or two dolomitic limestones $(1140 \mathrm{mg}$ or $1320 \mathrm{mg} \mathrm{Mg}$ ) in the soil and the values of these three as magnesium sources for ryegrass (Lolium multiflonum) were studied in pot experiment carried out over two growing seasons. The $\mathrm{pH}\left(\mathrm{CaCl}_{2}\right)$ of the very fine sand used as growth base was raised from its initial value of 4.9 to either 5.7 or 6.5 by the addition of calcitic limestone $(12 \mathrm{~g}$ or $24 \mathrm{~g}$ limestone $/ 3.9 \mathrm{~kg}$ of soil, respectively). The magnesium sources were compared at these three levels of soil acidity.

At $\mathrm{pH}\left(\mathrm{CaCl}_{2}\right) 6.5$ about $20 \%$ of the magnesium applied as magnesium sulphate was converted into a form not extractable in $1 \mathrm{M}$ neutral ammonium acetate. This not extractable magnesium appeared to be utilized slowly by ryegrass, which may indicate that magnesium bound in various $\mathrm{Al}-\mathrm{Mg}$ compounds in limed soil is to some extent available to plants.

At $\mathrm{pH}\left(\mathrm{CaCl}_{2}\right) 5.7$ and 6.5 around $70 \%$ and $85 \%$, respectively, of the magnesium derived from dolomitic limestones was not extractable in neutral ammonium acetate. The ryegrass was unable to utilize this not extractable magnesium during the two-year experimental period.

On an acid soil the dolomitic limestones used were a more effective source of magnesium than magnesium sulphate, though on almost neutral soil there was little difference between the two, despite the large difference in the amount of magnesium applied.
\end{abstract}

\section{Introduction}

Acidity and a low content of magnesium available to plants are characteristic features of several types of Finnish mineral soils, with the exception of glacial clays. It has thus become customary to use liming agents containing magnesium to improve the condition of the soil.

USHERWOOD and MILLER (1967) found that the magnesium uptake by 30-day-old maize seedlings decreased in soil treated with either coarse or fine dolomitic limestone (about $20 \% \mathrm{Mg}$ ) when the $\mathrm{pH}$ of the soil was raised from 5.3 to 6.7 by addition of $\mathrm{CaCO}_{3}$. There was no change in the uptake of magnesium by maize grown under the same conditions on soil treated with 
magnesium sulphate, hydrated lime $(18.7 \% \mathrm{Mg})$ or burnt lime $(21 \% \mathrm{Mg})$. In their study, WHITE and MUNRO (1981) found that the magnesium uptake by ryegrass from soil treated with magnesium sulphate $(50 \mathrm{ppm} \mathrm{Mg})$ or two levels of dolomitic limestone (50 and $240 \mathrm{ppm} \mathrm{Mg}$ ) decreased by $12 \%, 22 \%$ and $11 \%$, respectively, when the soil with an initial $\mathrm{pH}$ of 5.5 was treated with $800 \mathrm{ppm} \mathrm{Ca}$ as $\mathrm{CaCO}_{3}$ (4.5 t/ha lime).

Dolomitic limestone is less effective in neutralizing soil acidity than the same amount of calcitic limestone ground to the same degree of fineness (PERSSON 1976, HABY et al. 1979, JAAKKOLA and JOKINEN 1980). If the $\mathrm{pH}$ of soil containing only small amounts of plant available magnesium is raised by the application of calcitic limestone, the need for the addition of magnesium becomes even greater because some of the soil magnesium is converted in a form not extractable in neutral ammonium acetate (McLEAN 1956, ADAMS and HENDERSON 1962, KAILA 1974, GROVE et al. 1981, JOKINEN 1981). Similarly, some of the readily-soluble magnesium applied to the soil is converted into the not extractable form (JUO and UZU 1977, JOKINEN 1981).

The purpose of this study was to investigate the effect of changes in soil acidity on the availability to ryegrass of mgnesium given as either magnesium sulphate or two dolomitic limestones, and to compare these magnesium sources under the same conditions of soil acidity.

\section{Material and methods}

The material comprises the crops obtained from a pot experiment (acid very fine sand as growth base) performed outdoors, together with the results of plant and soil analyses. The pot experiment was carried out at the Institute of Agricultural Chemistry and Physics of the Agricultural Research Centre in 1979-80. The plant and soil samples were analysed at the Department of Agricultural Chemistry of the University of Helsinki.

Very fine sand, a Littorina soil, contains $72 \%$ of fraction $20-200 \mu \mathrm{m}$ and $10 \%$ of fraction less than $2 \mu \mathrm{m}$, has a $\mathrm{pH}\left(\mathrm{CaCl}_{2}\right) 4.9$ and an effective CEC $5.1 \mathrm{me} / 100 \mathrm{~g}$ and contains $3.9 \%$ organic carbon, in $1 \mathrm{M} \mathrm{KCl}$ extractable $(\mathrm{Al}+\mathrm{H}) 0.78 \mathrm{me} / 100 \mathrm{~g}$ and $\mathrm{Al} 0.28 \mathrm{me} / 100 \mathrm{~g}$, in $1 \mathrm{M}$ neutral ammonium acetate extractable $\mathrm{Mg} 0.38 \mathrm{me}, \mathrm{Ca} 4.35 \mathrm{me}$ and $\mathrm{K} 0.31$ me per $100 \mathrm{~g}$ soil.

The experiment began by weighing $4.5 \mathrm{~kg}$ of damp soil $(18 \%$ of moisture, corresponding to $3.9 \mathrm{~kg}$ of air-dry soil) into Mitscherlich pots. Calcitic limestone was mixed with the soil in amounts of $0 \mathrm{~g}\left(\mathrm{Ca}_{0}\right), 12 \mathrm{~g}\left(\mathrm{Ca}_{1}\right)$ or $24 \mathrm{~g}\left(\mathrm{Ca}_{2}\right)$ per pot and each amount of limestone was supplemented with the following magnesium treatments: no magnesium $\left(\mathrm{Mg}_{0}\right), 200 \mathrm{mg} /$ pot $\mathrm{Mg}$ as magnesium sulphate $\left(\mathrm{MgSO}_{4}\right), 12 \mathrm{~g}$ /pot dolomitic limestone 2 (D 2) or dolomitic limestone $1 \mathrm{H}(\mathrm{D} 1 \mathrm{H})$. Each treatment was replicated four times.

The calcitic limestone and dolomitic limestone 2 were of about the same degree of fineness, while dolomitic limestone $1 \mathrm{H}$ was finely ground (Table 1).

The amounts of magnesium supplied by the dolomitic limestones (D $2=$ $1140 \mathrm{mg} /$ pot, $\mathrm{D} 1 \mathrm{H}=1320 \mathrm{mg} /$ pot $\mathrm{Mg}$ ) were considerably greater than 
Table 1. Properties of the calcitic limestone and dolomitic limestones.

\begin{tabular}{llll}
\hline & $\begin{array}{l}\text { Calcitic } \\
\text { limestone }\end{array}$ & $\begin{array}{l}\text { Dolomitic } \\
\text { limestone 2 }\end{array}$ & $\begin{array}{l}\text { Dolomitic } \\
\text { limestone 1H }\end{array}$ \\
\hline $\begin{array}{l}\text { Fractions } \\
<\quad 0.15 \mathrm{~mm}, \%\end{array}$ & 64.1 & 55.0 & 100.0 \\
$0.15-2.00 \mathrm{~mm}, \%$ & 35.9 & 43,6 & \\
$>\quad 0.00 \mathrm{~mm}, \%$ & & 1.4 & \\
& & & 35.2 \\
Acid neutralizing capacity & 35.9 & 34.3 & \\
calculated as Ca, \% & & & 16.7 \\
Extractable in 1 M HCl & 36.1 & 20.9 & 11.0 \\
Ca, \% & 0.7 & 9.5 & \\
$\mathrm{Mg}, \%$ & & & \\
\hline
\end{tabular}

those supplied by magnesium sulphate, which means that the magnesium sources can best be compared in terms of the relative uptakes of magnesium. Applied to field conditions the smaller amount of limestone corresponds to liming of $5 \mathrm{t} / \mathrm{ha}$ and the higher amount to $10 \mathrm{t} / \mathrm{ha}$, while the magnesium sulphate application is equivalent to about $90 \mathrm{~kg} / \mathrm{ha}$ magnesium fertilization.

Magnesium content of the calcitic limestone $(0.73 \%)$ supplemented the magnesium content of the soil by $84 \mathrm{mg}\left(\mathrm{Ca}_{1}\right)$ or $168 \mathrm{mg}\left(\mathrm{Ca}_{2}\right)$. The amount of magnesium taken up by ryegrass from different sources was calculated for the different calcitic limestone levels as the difference from the soil which received no magnesium treatment.

It was possible to compare the three magnesium sources over almost the same $\mathrm{pH}\left(\mathrm{CaCl}_{2}\right)$ range, as each of the treatments $\mathrm{Ca}_{1}, \mathrm{Ca}_{1} \mathrm{MgSO}_{4}, \mathrm{D} 2$ and $\mathrm{D}$ $1 \mathrm{H}$ received $12 \mathrm{~g}$ of limestone per pot. Similar comparisons were also possible with the higher amount of limestone $(24 \mathrm{~g} / \mathrm{pot})$.

Ryegrass (Lolium multiflorum) was cultivated during the two growing seasons of the experiment and four crops were cut each season. The ryegrass was given sufficient quantities of the following nutrients: $\mathrm{NH}_{4} \mathrm{NO}_{3}$, $\mathrm{Ca}\left(\mathrm{H}_{2} \mathrm{PO}_{4}\right)_{2} \cdot \mathrm{H}_{2} \mathrm{O}, \mathrm{KCI}, \mathrm{H}_{3} \mathrm{BO}_{3}, \mathrm{MnSO}_{4} \cdot \mathrm{H}_{2} \mathrm{O}, \mathrm{CuSO}_{4} \cdot 5 \mathrm{H}_{2} \mathrm{O}, \mathrm{ZnSO}_{4} \cdot$ $7 \mathrm{H}_{2} \mathrm{O}$ and $\mathrm{Na}_{2} \mathrm{MoO}_{4} \cdot 2 \mathrm{H}_{2} \mathrm{O}$. Nitrogen and potassium fertilizers were applied each year before sowing and after the second cut, while the other nutrients were mixed into the entire soil batch prior to sowing.

The crops were dried at $105^{\circ} \mathrm{C}$ overnight and ground in a Willey mill in preparation for analysis. The eight crops obtained from each pot were analysed separately. The total calcium and magnesium contents of the plant samples were determined by wet combustion $\left(\mathrm{H}_{2} \mathrm{SO}_{4}: \mathrm{HCIO}_{4}: \mathrm{HNO}_{3}=\right.$ $1: 2: 10$, SCHARRER and MUNK 1956) followed by atomic absorption spectrophotometric analysis of the solution.

Calcium and magnesium contents of the liming agents were determined from the HCI extract obtained by allowing $3 \mathrm{~g}$ of limestone to react with 125 $\mathrm{ml}$ of $1 \mathrm{M} \mathrm{HCI}$ for one hour on a boiling water bath. The same extract was used to titrate the amount of acid neutralized by the limestone; calculated as calcium, this gives the neutralizing capacity of the limestone. 
At the end of the first growing season a soil sample was taken from each pot for determination of $\mathrm{pH}\left(\mathrm{CaCI}_{2}\right)$. At the end of the second growing season soil samples of about half a litre were taken from the pots for analysis. The analyses were performed on samples dried at room temperature.

The soil was suspended in $0.01 \mathrm{M} \mathrm{CaCI}_{2}$ solution in the proportions $1: 2.5$ by volume and the $\mathrm{pH}$ determined after allowing the suspension to equilibrate for four hours. The magnesium and calcium available to plants was extracted from the soil with $1 \mathrm{M}$ neutral ammonium acetate. The effective $\mathrm{CEC}$ was determined as the sum of $(\mathrm{Ca}+\mathrm{Mg})$ and $(\mathrm{Al}+\mathrm{H})$ extractable in $1 \mathrm{M}$ KCI (KAILA 1971)

The growing season 1979 was extremely wet. The volume of water that drained through the soil into the basin under the pot was so high (1000-1500 $\mathrm{ml}$ ) at the end of the experiment that it could not be re-adsorbed into the soil. Because of this, the following procedure adopted for each pot: the volume of the water was measured, a sample was taken for determination of magnesium and calcium, and the water was then poured away. The results were used to calculate the amounts of calcium and magnesium leached out of the soil by the rainwater.

The reliability of the results was studied by analysis of variance (COCHRAN and COX 1966). Duncan's new multiple range test was used to test the significant differences between the various treatments. In the tables, the results provided with the same letter do not differ from each other $(P=0.05)$.

\section{Results}

The calcium and magnesium contents of the water that had drained through the soil at the end of the first growing season may indicate the susceptibility of these two nutrients to leaching from the soil treated with the various agents over a short space of time. The water contained about $9 \%$ of the magnesium from magnesium sulphate and about $1 \%$ of the magnesium from dolimitic limestone 2 (Table 2). Raising the $\mathrm{pH}\left(\mathrm{CaCI}_{2}\right)$ of the soil did

Table 2. Calcium and magnesium (mg/pot) in the water leached through the soil at the end of the first growing season.

\begin{tabular}{lcccc}
\hline & $\mathrm{Mg}_{0}$ & $\mathrm{MgSO}_{4}$ & $\mathrm{D} \mathrm{2}$ & $\mathrm{D} 1 \mathrm{H}$ \\
\hline & & $\mathrm{Mg} \mathrm{mg} /$ pot & & \\
$\mathrm{Ca}_{0}$ & $3^{\mathrm{a}}$ & $19^{\text {cd }}$ & $15^{\mathrm{bc}}$ & $26^{\mathrm{d}}$ \\
$\mathrm{Ca}_{1}$ & $2^{\mathrm{a}}$ & $12^{\mathrm{bc}}$ & $13^{\mathrm{bc}}$ & $13^{\mathrm{bc}}$ \\
$\mathrm{Ca}_{2}$ & $7^{\mathrm{ab}}$ & $18^{\text {cd }}$ & $9^{\mathrm{b}}$ & $9^{\mathrm{b}}$ \\
& & $\mathrm{Ca} \mathrm{mg/pot}$ & & \\
$\mathrm{Ca}_{0}$ & $155^{\mathrm{b}}$ & $197^{\text {cd }}$ & $119^{\mathrm{a}}$ & $111^{\mathrm{a}}$ \\
$\mathrm{Ca}_{1}$ & $203^{\text {cde }}$ & $234^{\text {def }}$ & $234^{\text {def }}$ & $166^{\mathrm{bc}}$ \\
$\mathrm{Ca}_{2}$ & $241^{\text {ef }}$ & $344^{\mathrm{b}}$ & $245^{\text {ef }}$ & $252^{f}$ \\
\hline
\end{tabular}


not significantly affect the amount of magnesium removed from the soil along with the water. Below $\mathrm{pH}\left(\mathrm{CaCI}_{2}\right) 6$ the water contained about $2 \%$ of the magnesium from dolomitic limestone $1 \mathrm{H}$, but raising the $\mathrm{pH}\left(\mathrm{CaCI}_{2}\right)$ considerably reduced this amount. Application of magnesium sulphate fertilizer appeared to increase the amount of calcium leached from both unlimed and heavily limed soils.

The $\mathrm{pH}\left(\mathrm{CaCl}_{2}\right)$ of soils treated with calcitic limestone $\left(\mathrm{Ca}_{1}\right)$ was significantly higher than that of soils treated with the same amount of dolomitic limestones (Table 3). Dolomitic limestone $1 \mathrm{H}$, which was more finely ground than the others, appeared to have increased the $\mathrm{pH}\left(\mathrm{CaCl}_{2}\right)$ value at the end of the first growing period by less than had dolomitic limestone 2. Above $\mathrm{pH}\left(\mathrm{CaCl}_{2}\right) 6$, the capacity of the dolomitic limestones to neutralize soil acidity was significantly less than that of calcitic limestone.

When the dolomitic limestones were used, the effective CEC increased along with $\mathrm{pH}\left(\mathrm{CaCl}_{2}\right)$, though significantly less than was the case when calcitic limestone was used (Table 3). Close to $\mathrm{pH}\left(\mathrm{CaCl}_{2}\right) 6.5$ the increase in effective CEC induced by dolomitic limestone $1 \mathrm{H}$ was smaller than that produced by dolomitic limestone 2 . In the other treatments neither the application of magnesium sulphate nor the increase in the magnesium content

Table 3. Soil $\mathrm{pH}\left(\mathrm{CaCl}_{2}\right)$, effective $\mathrm{CEC}(\mathrm{me} / 100 \mathrm{~g}$ soil), contents of magnesium and calcium extractable in $1 \mathrm{M}$ neutral ammonium acetate $(\mathrm{mg} / 100 \mathrm{~g}$ soil $)$ and equivalent ratio $\mathrm{Ca} / \mathrm{Mg}$ at the end of the experiments.

\begin{tabular}{|c|c|c|c|c|}
\hline & $\mathrm{Mg}_{0}$ & $\mathrm{MgSO}_{4}$ & D 2 & D $1 \mathrm{H}$ \\
\hline & \multicolumn{4}{|c|}{$\mathrm{pH}\left(\mathrm{CaCl}_{2}\right)$} \\
\hline $\mathrm{Ca}_{0}$ & $4.5^{\mathrm{a}}$ & $4.5^{2}$ & $5.5^{b}$ & $5.4^{b}$ \\
\hline $\mathrm{Ca}_{1}$ & $5.7^{c}$ & $5.7^{\circ}$ & $6.3^{\mathrm{d}}$ & $6.2^{\mathrm{d}}$ \\
\hline \multirow[t]{2}{*}{$\mathrm{Ca}_{2}$} & $6.5^{\circ}$ & $6.5^{\circ}$ & $6.7^{i}$ & $6.7^{i}$ \\
\hline & \multicolumn{4}{|c|}{ Effective CEC me $/ 100 \mathrm{~g}$ soil } \\
\hline $\mathrm{Ca}_{0}$ & $5.5^{\mathrm{a}}$ & $5.4^{a}$ & $7.6^{b}$ & $7.4^{b}$ \\
\hline $\mathrm{Ca}_{1}$ & $8.9^{c}$ & $9.3^{c}$ & $10.7^{d}$ & $10.9^{d}$ \\
\hline \multirow[t]{2}{*}{$\mathrm{Ca}_{2}$} & $12.4^{e}$ & $12.5^{\circ}$ & $14.4^{8}$ & $13.2^{f}$ \\
\hline & \multicolumn{4}{|c|}{$\mathrm{Mg} \mathrm{mg} / 100 \mathrm{~g}$ soil } \\
\hline $\mathrm{Ca}_{0}$ & $1.0^{2}$ & $2.9^{\mathrm{ab}}$ & $10.7^{f}$ & $16.8^{8}$ \\
\hline $\mathrm{Ca}_{1}$ & $1.1^{2}$ & $3.9^{\mathrm{bc}}$ & $6.8^{e}$ & $10.7^{f}$ \\
\hline \multirow[t]{2}{*}{$\mathrm{Ca}_{2}$} & $1.4^{2}$ & $4.2^{\mathrm{bc}}$ & $4.8^{\mathrm{cd}}$ & $6.0^{\mathrm{de}}$ \\
\hline & \multicolumn{4}{|c|}{ Ca mg/100 soil } \\
\hline $\mathrm{Ca}_{0}$ & $76^{2}$ & $73^{2}$ & $128^{c}$ & $113^{b}$ \\
\hline $\mathrm{Ca}_{1}$ & $172^{d}$ & $174^{d}$ & $200^{\circ}$ & $198^{e}$ \\
\hline \multirow[t]{2}{*}{$\mathrm{Ca}_{2}$} & $245^{f}$ & $241^{f}$ & $277^{8}$ & $252^{f}$ \\
\hline & \multicolumn{4}{|c|}{ Equivalent ratio $\mathrm{Ca} / \mathrm{Mg}$} \\
\hline $\mathrm{Ca}_{0}$ & $27.1^{f}$ & $9.6^{b}$ & $4.5^{2}$ & $2.5^{2}$ \\
\hline $\mathrm{Ca}_{\mathrm{a}_{1}}$ & $62.4^{8}$ & $16.3^{d}$ & $10.8^{\mathrm{bc}}$ & $6.9^{a b}$ \\
\hline $\mathrm{Ca}_{2}$ & $65.0^{\mathrm{B}}$ & $21.5^{\mathrm{e}}$ & $21.3^{\mathrm{e}}$ & $15.5^{\mathrm{ed}}$ \\
\hline
\end{tabular}


of the dolomitic limestone had any significant effect on the effective CEC.

Increasing the amount of calcitic limestone appeared to cause a slight increase at the end of the experiment in the amount of magnesium extractable in $1 \mathrm{M}$ neutral ammonium acetate in the soils not treated with magnesium, since the calcitic limestone contained $0.73 \%$ magnesium (Table 3 ). The same trend was observed with soils treated with magnesium sulphate. At the calcitic limestone levels $\mathrm{Ca}_{0}$ and $\mathrm{Ca}_{1}$ the addition of magnesium as dolomitic limestones increased the soil's content of magnesium extractable in ammonium acetate significantly more than when magnesium sulphate was applied. The increase in magnesium content was greater with dolomitic limestone $1 \mathrm{H}$ than with dolomitic limestone 2. Supplementing calcitic limestone $\left(\mathrm{Ca}_{2}\right)$ with dolomitic limestone did not have quite as favourable an effect on the magnesium content of the soil as the above-described. Increasing the $\mathrm{pH}\left(\mathrm{CaCl}_{2}\right)$ of the soil produced a sharp decrease in the neutral ammonium acetate extractable magnesium content of the soils treated with dolimitic limestones.

As a result of the different calcium contents of the liming agents, calcitic limestone raised the calcium content of the soil more than the same amount of the dolomitic limestones (Table 3). The differences in the calcium content of the soil brought about by the application of the dolomitic limestones may also be due to the differences in calcium content of these limestones.

The application of calcitic limestone $\left(\mathrm{Ca}_{1}\right)$ increased the equivalent ratio $\mathrm{Ca} / \mathrm{Mg}$ to almost three times the value for unlimed soil and to more than ten times the value for soil treated with the same amount of dolomitic limestone 2 (Table 3 ). The dolomitic limestones decreased the ratio $\mathrm{Ca} / \mathrm{Mg}$ significantly more than did magnesium sulphate at the $\mathrm{Ca}_{0}$ and $\mathrm{Ca}_{1}$ levels of calcitic limestone, though not at the $\mathrm{Ca}_{2}$ level. The amount of magnesium per pot provided by the different magnesium sources was not the same.

Irrespective of the liming agent, liming in itself appeared to produce a significant increase in the total yield of ryegrass obtained from the eight cuts (Table 4.) The yields obtained with the magnesium sources studied were the same at each level of calcitic limestone. The yields obtained from the first cut without calcitic limestone were significantly higher than those obtained with the high amount of this lime (results not presented). It was not until the sixth and seventh cuts that the yields without calcitic limestone were significantly lower than those obtained with liming.

The mean magnesium content of stands grown with magnesium sulphate was not dependent on the amount of calcitic limestone (Table 4). The mean magnesium content of stands cultivated with dolomitic limestone $1 \mathrm{H}$ decreased significantly at every stage as the amount of calcitic limestone was increased from $\mathrm{Ca}_{0}$ to $\mathrm{Ca}_{2}$. The supply of calcitic limestone decreased the mean magnesium content of the stands obtained with the dolomitic limestone, though there was no difference between the two amounts of calcitic limestone.

The mean calcium content of stands cultivated without calcitic limestone but with either magnesium sulphate or dolomitic limestone $1 \mathrm{H}$ was lower than that of plants produced with dolomitic limestone 2 (Table 4). The 
Table 4. Total ryegrass yields ( $\mathrm{g} / \mathrm{pot}$ ), mean magnesium and calcium contents ( $\mathrm{mg} / \mathrm{g}$ dry matter) of the stands ( 8 cuts) and the total magnesium uptake by ryegrass (mg/pot).

\begin{tabular}{|c|c|c|c|c|}
\hline & $\mathrm{Mg}_{0}$ & $\mathrm{MgSO}_{4}$ & D 2 & D $1 \mathrm{H}$ \\
\hline & \multicolumn{4}{|c|}{ Total yield g/pot dry matter } \\
\hline $\mathrm{Ca}_{0}$ & $83.8^{\mathrm{a}}$ & $86.7^{\mathrm{ab}}$ & $91.0^{\mathrm{bc}}$ & $88.9^{\mathrm{bc}}$ \\
\hline $\mathrm{Ca}_{1}$ & $91.3^{c}$ & $91.9^{c}$ & $92.3^{c}$ & $88.7^{b c}$ \\
\hline \multirow[t]{2}{*}{$\mathrm{Ca}_{2}$} & $92.0^{c}$ & $88.9^{\mathrm{bc}}$ & $91.7^{c}$ & $91.8^{c}$ \\
\hline & \multicolumn{4}{|c|}{$\mathrm{Mg} \mathrm{mg/g} \mathrm{dry} \mathrm{matter}$} \\
\hline $\mathrm{Ca}_{0}$ & $1.7^{2}$ & $2.5^{\mathrm{bc}}$ & $2.9^{\mathrm{d}}$ & $3.3^{\mathrm{e}}$ \\
\hline $\mathrm{Ca}_{1}$ & $1.8^{\mathrm{a}}$ & $2.4^{b}$ & $2.5^{\mathrm{bc}}$ & $2.8^{\text {cd }}$ \\
\hline \multirow[t]{2}{*}{$\mathrm{Ca}_{2}$} & $1.8^{\mathrm{a}}$ & $2.3^{\mathrm{b}}$ & $2.3^{\mathrm{b}}$ & $2.3^{\mathrm{b}}$ \\
\hline & \multicolumn{4}{|c|}{ Ca mg/g dry matter } \\
\hline $\mathrm{Ca}_{0}$ & $8.7^{\mathrm{ab}}$ & $8.0^{\mathrm{a}}$ & $9.2^{\mathrm{b}}$ & $8.3^{2}$ \\
\hline $\mathrm{Ca}_{1}$ & $10.6^{\mathrm{cd}}$ & $10.1^{\mathrm{c}}$ & $10.2^{c}$ & $10.3^{c}$ \\
\hline \multirow[t]{2}{*}{$\mathrm{Ca}_{2}$} & $11.1^{\mathrm{d}}$ & $10.8^{\mathrm{cd}}$ & $10.8^{\text {ed }}$ & $10.3^{c}$ \\
\hline & \multicolumn{4}{|c|}{ Mg uptake mg/pot } \\
\hline $\mathrm{Ca}_{0}$ & $140^{2}$ & $217^{\mathrm{ed}}$ & $264^{f}$ & $294^{8}$ \\
\hline $\mathrm{Ca}_{1}$ & $166^{b}$ & $225^{\mathrm{cd}}$ & $234^{\mathrm{de}}$ & $244^{e}$ \\
\hline $\mathrm{Ca}_{2}$ & $171^{b}$ & $207^{c}$ & $211^{c}$ & $214^{e}$ \\
\hline
\end{tabular}

differences in the calcium contents of the stands brought about by the different magnesium sources were not significant at either of the two calcitic limestone levels.

The total amount of magnesium taken up by ryegrass crops without magnesium sources increased as the amount of calcitic limestone increased, since along with the calcitic limestone introduced into the soil $84 \mathrm{mg} /$ pot or $168 \mathrm{mg} /$ pot of magnesium (Table 4). The magnesium uptake by ryegrass grown with magnesium sulphate was independent of the soil acidity. When dolomitic limestones were used the magnesium uptake decreased as the $\mathrm{pH}\left(\mathrm{CaCl}_{2}\right)$ of the soil increased. Without calcitic limestone the crops that took up most magnesium were those cultivated with dolomitic limestone $1 \mathrm{H}$, though, close to $\mathrm{pH}\left(\mathrm{CaCl}_{2}\right) 6.5$, the magnesium uptake was independent of the magnesium source. Even the lower amount of calcitic limestone appeared to cancel out the differences between magnesium sources.

The recovery of magnesium from magnesium sulphate (the difference between magnesium treatment and no magnesium) was at $\mathrm{Ca}_{0}$ and $\mathrm{Ca}_{1}$ levels of calcitic limestone almost the same in both years (Table 5). In near neutral soil about $30 \%$ of the total magnesium uptake occurred during the first year. The ryegrass took up about $35 \%$ of the total magnesium uptake supplied by the dolomitic limestones at the $\mathrm{Ca}_{0}$ and $\mathrm{Ca}_{1}$ levels of calcitic limestone during the first growing season, whereas at $\mathrm{pH}\left(\mathrm{CaCl}_{2}\right) 6.5$ the uptake was divided evenly between the two years.

The appparent recovery of magnesium from the various sources was greatest when calcitic limestone was not used (Table 5). The ryegrass crops recovered a greater proportion of the magnesium from magnesium sulphate 
Table 5. Apparent recovery of added magnesium (mg/pot) applied as magnesium sulphate or dolomitic limestones in the first and second growing season, and apparent recovery of the magnesium for the entire experimental period $(\%)$.

Apparent recovery of magnesium applied as magnesium sulphate or dolomitic limestones

\begin{tabular}{|c|c|c|c|c|c|c|c|c|}
\hline \multicolumn{6}{|c|}{$\mathrm{Mg} \mathrm{mg} /$ pot } & \multirow{2}{*}{\multicolumn{3}{|c|}{$\begin{array}{c}\% \\
\text { Total }\end{array}$}} \\
\hline \multicolumn{3}{|c|}{ 1st year } & \multicolumn{3}{|c|}{ 2nd year } & & & \\
\hline $\mathrm{MgSO}_{4}$ & D 2 & D $1 \mathrm{H}$ & $\mathrm{MgSO}_{4}$ & D 2 & D $1 \mathrm{H}$ & $\mathrm{MgSO}_{4}$ & D 2 & D $1 \mathrm{H}$ \\
\hline $37^{\mathrm{bc}}$ & $45^{c}$ & $61^{d}$ & $40^{\text {bed }}$ & $79^{e}$ & $93^{e}$ & $39^{e}$ & $11^{\mathrm{b}}$ & $12^{\mathrm{b}}$ \\
\hline $26^{b}$ & $25^{\mathrm{b}}$ & $24^{\mathrm{b}}$ & $33^{\mathrm{abc}}$ & $43^{\text {cd }}$ & $54^{d}$ & $30^{d}$ & $6^{a} 6^{a}$ & \\
\hline $11^{2}$ & $19^{\mathrm{ab}}$ & $21^{\mathrm{ab}}$ & $25^{\mathrm{ab}}$ & $21^{a}$ & $22^{a}$ & $18^{c}$ & $4^{2}$ & $3^{a}$ \\
\hline
\end{tabular}

than from the dolomitic limestones. There were no differences in the apparent recovery of magnesium from the dolomitic limestones at the $\mathrm{pH}\left(\mathrm{CaCl}_{2}\right)$ values studied.

When magnesium sulphate was used, the magnesium uptake by ryegrass from this magnesium source, plus the increase in neutral ammonium acetate extractable magnesium content of the soil, plus the magnesium contained in the water that drained through the soil was roughly the same at each of the $\mathrm{pH}\left(\mathrm{CaCl}_{2}\right)$ values studied (Table 6). The proportion of magnesium not extractable in neutral ammonium acetate of the magnesium added as magnesium sulphate was greatest $(22 \%)$ in soil given the heavy liming $\left(\mathrm{Ca}_{2}\right)$.

About $50 \%$ of the magnesium added as dolomitic limestones was not extractable in neutral ammonium acetate when the soil $\mathrm{pH}\left(\mathrm{CaCl}_{2}\right)$ was not adjusted by the addition of calcitic limestone. The proportion of the not extractable magnesium of the added magnesium increased as the $\mathrm{pH}\left(\mathrm{CaCl}_{2}\right)$

Table 6. The proportion of magnesium added in the various sources found in the yields and the soil, leached out of the soil, and remaining in the soil in a form not extractable in $1 \mathrm{M}$ neutral ammonium acetate $(\mathrm{mg} / \mathrm{pot}, \%)$.

\begin{tabular}{|c|c|c|c|c|c|c|c|c|}
\hline & & $\begin{array}{l}\text { Added } \\
\text { magnesium } \\
\text { mg/pot }\end{array}$ & $\begin{array}{l}\text { Magnesium } \\
\text { uptake } \\
\mathrm{mg} / \mathrm{pot}\end{array}$ & $\begin{array}{l}\text { Leached } \\
\text { magnesium } \\
\text { mg/pot }\end{array}$ & $\begin{array}{l}\text { Magnesium } \\
\text { in soil } \\
\text { extract. } \\
\text { amm. acet. } \\
\mathrm{mg} / \text { pot }\end{array}$ & $\begin{array}{l}\text { Total } \\
\text { of } \\
\text { analysed } \\
\text { magnesium } \\
\text { mg/pot }\end{array}$ & $\begin{array}{c}\text { Magnesiur } \\
\text { not extrac } \\
\text { ammoniun } \\
\mathrm{mg} / \text { pot }\end{array}$ & $\begin{array}{l}\text { soil } \\
\text { in } \\
\text { tate } \\
\%\end{array}$ \\
\hline \multirow[t]{3}{*}{$\mathrm{Ca}_{0}$} & $\mathrm{MgSO}_{4}$ & 200 & $77^{\circ}$ & $16^{b}$ & $74^{2}$ & $167^{2}$ & $33^{2}$ & $17^{b}$ \\
\hline & D 2 & 1140 & $124^{d}$ & $12^{\mathrm{b}}$ & $378^{e}$ & $514^{c}$ & $626^{\circ}$ & $55^{d}$ \\
\hline & D $1 \mathrm{H}$ & 1320 & $154^{e}$ & $23^{c}$ & $616^{f}$ & $793^{d}$ & $527^{b}$ & $40^{c}$ \\
\hline \multirow[t]{3}{*}{$\mathrm{Ca}_{1}$} & $\mathrm{MgSO}_{4}$ & 200 & $59^{\mathrm{bc}}$ & $10^{b}$ & $109^{b}$ & $178^{2}$ & $22^{2}$ & $11^{2}$ \\
\hline & D 2 & 1140 & $68^{c}$ & $11^{\mathrm{b}}$ & $222^{\mathrm{d}}$ & $301^{a b}$ & $839^{d}$ & $74^{f}$ \\
\hline & D $1 \mathrm{H}$ & 1320 & $78^{c}$ & $11^{b}$ & $374^{e}$ & $463^{b c}$ & $857^{d}$ & $65^{e}$ \\
\hline \multirow[t]{3}{*}{$\mathrm{Ca}_{2}$} & $\mathrm{MgSO}_{4}$ & 200 & $36^{2}$ & $11^{\mathrm{b}}$ & $109^{b}$ & $156^{2}$ & $44^{2}$ & $22^{b}$ \\
\hline & D 2 & 1140 & $40^{\mathrm{ab}}$ & $2^{2}$ & $132^{\mathrm{b}}$ & $174^{2}$ & $966^{\circ}$ & $85^{8}$ \\
\hline & D $1 \mathrm{H}$ & 1320 & $43^{\mathrm{ab}}$ & $2^{2}$ & $179^{c}$ & $224^{a}$ & $1096^{f}$ & $83^{8}$ \\
\hline
\end{tabular}


of the soil increased, reaching about $85 \%$ around $\mathrm{pH}$ 6.5. If the experiment had been continued for longer than two years the proportion of not extractable magnesium derived from dolomitic limestones would have been lower than that found now at $\mathrm{Ca}_{1}$ level of calcitic limestone, since the magnesium uptake by ryegrass during the second year was greater than during the first.

\section{Discussion}

The effect of dolomitic limestone $1 \mathrm{H}$ on the $\mathrm{pH}\left(\mathrm{CaCl}_{2}\right)$ of the soil at the end of the first growing season was smaller than that of dolomitic limestone 2. At the end of the second growing period the two limestones had neutralized the soil almost equally effectively. Liming affects the $\mathrm{pH}$ of the soil more rapidly in a pot experiment than in field experiments (JAAKKOLA and JOKINEN 1980). The higher the magnesium content of the limestone the more finely ground it should be if the various types of limestone are to neutralize the soil to roughly the same extent, since dolomitic limestone dissolves more slowly than calcitic limestone in soil (MEYER and VOLK 1952, HABY et al. 1979). The ability of dolomitic limestones to neutralize soil whose $\mathrm{pH}\left(\mathrm{CaCl}_{2}\right)$ had been raised to about 6.5 with calcitic limestone was virtually non-existent, despite the fact that it was finely ground (PEDERSEN 1978).

Liming increases the effective CEC of the soil since the number of negatively charged sites increases and calcium and magnesium occupy most of these sites (MUNS 1976). In this pot experiment the dolomitic limestones seemed to have a smaller effect on the effective CEC than the same amount of calcitic limestone. It has also been reported that the effective CEC of soil is not affected by either magnesium sulphate (GROVE et al. 1981, JOKINEN 1981) or magnesium carbonate (GROVE et al. 1981) because of the slight changes in the $\mathrm{pH}$ of the soil.

During the two years of this pot experiment about $20 \%$ of the readily soluble magnesium applied as magnesium sulphate was converted into a form not extractable in neutral ammonium acetate at $\mathrm{pH}\left(\mathrm{CaCl}_{2}\right) 6.5$, and about 11 $\%$ at $\mathrm{pH}\left(\mathrm{CaCl}_{2}\right)$ 5.7. Since the $1 \mathrm{M} \mathrm{KCl}$ extractable $\mathrm{Al}$ content of the soil was low $(0.28 \mathrm{me} / 100 \mathrm{~g}$ soil, $5 \%$ of the effective CEC) the formation of various not extractable Al-Mg compounds (HUNSAKER and PRATT 1970, McBRIDE 1978 ) or other reactions due to the high aluminium content of the soil (KINNIBURG et al. 1976, CHAN et al. 1979, GROVE et al. 1981) do not alone adequately explain the conversion of magnesium into a not in ammonium acetate extractable form.

At the end of the experiment $85 \%$ of the magnesium applied as dolomitic limestones was not extractable in neutral ammonium acetate at the $\mathrm{Ca}_{2}$ level of calcitic limestone. According to USHERWOOD and MILLER (1967) there were very small differences in the magnesium uptake by corn from hydrated lime, burnt lime and magnesium sulphate at all the five $\mathrm{pH}$ levels between 4.4 and 6.7. The magnesium uptake from two dolomitic limestones was signifi- 
cantly lower than from the magnesium sources mentioned above. This may indicate that the magnesium from dolomitic limestones is to a greater extent converted to a not extractable form than from other magnesium sources at a high $\mathrm{pH}$ level. In addition to the very low solubility of dolomitic limestones (USHERWOOD and MILLER 1967) the formation of insoluble magnesium carbonates and phosphates may take place (LIEBHARDT 1979) in soils limed with calcitic limestone.

GROVE et al. (1981) found that the conversion of magnesium in soil into not in ammonium acetete extractable form takes place rapidly, within the space of 1-25 days. The results of this pot experiment also support this, since in unlimed soil the first-cut crops took up $5.2 \mathrm{mg} / \mathrm{pot}$ of the magnesium given as magnesium sulphate and $1.3 \mathrm{mg} /$ pot of the magnesium when the soil was limed around $\mathrm{pH}\left(\mathrm{CaCl}_{2}\right)$ 5.7. Nevertheless, it appears that this not in neutral ammonium acetate extractable magnesium is gradually released and available to the plants. At around $\mathrm{pH}\left(\mathrm{CaCl}_{2}\right) 6.5$ the magnesium uptake by ryegrass from magnesium sulphate was about twice as high during the second year as during the first. The uptake of magnesium on unlimed soil was the same in both years.

At about $\mathrm{pH}\left(\mathrm{CaCl}_{2}\right) 6.5$ the ryegrass took up the same amount (mg/pot) of magnesium from both dolomitic limestones and magnesium sulphate, despite the fact that there was a marked difference in the amount of magnesium applied. The neutral ammonium acetate insoluble magnesium compounds from dolomitic limestones were not available to the ryegrass during the two years of the experiment, since the uptake of magnesium was the same in both years. In the absence of calcitic limestone the magnesium applied as dolomitic limestone was more easily available to the ryegrass during the second year than the first, and the total uptake of magnesium was considerably higher than in soil limed with calcitic limestone to around $\left.\mathrm{pH}) \mathrm{CaCl}_{2}\right)$ 6.5. The results obtained at the $\mathrm{Ca}_{1}$ level of calcitic limestone showed the same trend as those obtained without lime.

In terms of the magnesium supply and the amount of magnesium available to the plants, dolomitic limestones are better liming agents for acid soils than calcitic limestone and better sources of magnesium than magnesium sulphate. The magnesium fertilization applied to soils with a high $\mathrm{pH}$ should be in the form of magnesium sulphate, irrespective of the risk of the formation of magnesium compounds not extractable in neutral ammonium acetate because this insoluble magnesium is more readily available to the plants than when dolomitic limestone is used.

At the end of the first growing season there was a clear increase in the amount of calcium leached from both unlimed soil and from soil treated with calcitic limestone as a result of the application of magnesium sulphate. This is due to the formation of soluble gypsum $\left(\mathrm{CaSO}_{4} \cdot 2 \mathrm{H}_{2} \mathrm{O}\right)$ from the calcium ions either present in the soil or supplied with the liming agent and from the sulphate ions supplied in the magnesium sulphate.

The limestone sold in Finland bearing the name of magnesium containing calcitic limestone has an average magnesium content of $5 \%$ (range 3-7 \% $\mathrm{Mg})$. The total limestone amount $(24 \mathrm{~g} / \mathrm{pot})$ applied in this experiment in 
treatments $\mathrm{Ca}_{1} \mathrm{D} 2$ and $\mathrm{Ca}_{1} \mathrm{D} 1 \mathrm{H}$ contained $4.5 \%$ and $6 \%$ magnesium, respectively, while the treatments $\mathrm{Ca}_{2} \mathrm{D} 2$ and $\mathrm{Ca}_{2} \mathrm{D} 1 \mathrm{H}$ (36 g/pot of lime) contained $2.3 \%$ and $3 \%$ magnesium, respectively. The results obtained with these treatments may give some indication of the effects of the magnesium containing calcitic limestone on the yield, the nutrient content of the crop and the properties of the soil.

Acknowledgement: I am grateful to the Foundation for Research of Kemira Oy for a grant received for the completion of this research.

\section{REFERENCES}

ADAMS, F. \& HENDERSON, J. B. 1962. Magnesium availability as affected by deficient and adequate levels of potassium and lime. Soil Sci. Soc. Amer. Proc. 26: 65-68.

CHAN, K. Y., DAVEY, B. G. \& GEERING, H. R. 1979. Adsorption of magnesium and calcium by a soil with variable charge. Soil Sci. Soc. Amer. J. 43: 301-304.

COCHRAN, W. G. \& COX, G. M. 1966. Experimental designs. 2nd Ed. 611 p. New York.

GROVE, J. H., SUMNER, M. E. \& SYERS, J. K. 1981. Effect of lime on exchangeable magnesium in variable surface charge soils. Soil Sci. Soc. Amer. J. 45: 497-500.

HABY, A. V., ANDERSON, W. B. \& WELCH, C. D. 1979. Effect of limestone variables on amendment of acid soils and production of corn and coastal bermudagrass. Soil Sci. Soc. Amer. J. 43: 343-347.

HUNSAKER, V. E. \& PRATT, P. T. 1970. The formation of mixed magnesium-aluminum hydroxides in soil materials. Soil Sci. Soc. Amer. Proc. 34: 813-816.

JAAKKOLA. A. \& JOKINEN, R. 1980. Comparison of fine and coarse limestones in pot and field experiments. Ann. Agric. Fenn. 19: 108-124.

JOKINEN, R. 1981. Effect of liming on the magnesium status of some mineral soils and on the fate of fertilizer magnesium. J. Scient. Agric. Soc. Finl. 53: 126-137.

JUO, A. S. R. \& UZU, F. O. 1977. Liming and nutrient interactions in two ultisols from southern Nigeria. Plant and Soil 47: 419-430.

KAILA, A. 1971. Effective cation-exchange capacity in Finnish mineral soils. J. Scient. Agric. Soc. Finl. 43: 178-186.

- 1974. Effect of liming on basic exchangeable cations of soil. J. Scient. Agric. Soc. Finl. 46: 167-174.

KINNIBURG, D. G., JACKSON, M. L. \& SYERS, J. K. 1976. Adsorption of alkaline earth, transition, and heavy metal cations by hydrous oxide gels of iron and aluminum. Soil Sci. Soc. Amer. J. 40: 796-799.

LIEBHARDT, W. C. 1979. Corn yield as affected by lime rate and type on a coastal plain soil. Soil Sci. Soc. Amer. J. 43: 985-988.

McBRIDE, M. B. 1978. Retention of $\mathrm{Cu}^{2+}, \mathrm{Ca}^{2+}, \mathrm{Mg}^{2+}$ and $\mathrm{Mn}^{2+}$ by amorphous alumina. Soil Sci. Soc. Amer. J. 42: 27-31.

McLEAN, A. J. 1956. Influence of addition of lime to soils on the availability of potassium and other cations for alfalfa. Can. J. Agric. Sci. 36: 213-220.

MEYER, T. A. \& VOLK, G. W. 1952. Effect of particle size of limestones on soil reaction, exchangeable cations, and plant growth. Soil. Sci. 73: 37-52.

MUNS, D. N. 1976. Heterovalent cation exchange equilibria in soils with variable and heterogeneous charge. Soil Sci. Soc. Amer. J. 40: 841-845.

PEDERSEN, M. B. 1978. Nogle kalkningsmidlers reaktivitetsprofil og partikelstørrelsens inflydelse på denne. Nord. Jordbr.forskn. 60: 716-717.

PERSSON, J. 1974. Dolomitens kalk- och magnesiumeffekt. En orienterande undersökning. Rapp. Avdelningen Västnäringslära 76: 1-5, 13 tab., 4 fig.

SCHARRER, K. \& MUNK, H. 1956. Zur Methodik aer nassen Veraschung in der agrikulturchemischen Analyse. Agrochimica 1: 44-55. 
USHERWOOD, N. R. \& MILLER, J. R. 1967. Effect of soil pH on the availability of magnesium to corn (Zea mays L.) from magnesium sulfate and high magnesium liming materials. Soil Sci. Soc. Amer. Proc. 31: 390-393.

WHITE, R. P. \& MUNRO. D. C. 1981. Magnesium availability and plant uptake from different magnesium sources in a greenhouse experiment. Can. J. Soil Sci. 61:397-400.

Ms received March 22, 1982

\title{
SELOSTUS
}

\section{Kalkituksen vaikutus magnesiumsulfaatin ja dolomiittikalkkien arvoon raiheinän magnesiumin lähteenä}

\author{
Raili Jokinen \\ Helsingin yliopisto, Maanviljelyskemian laitos, 00710 Helsinki 71
}

Kaksi vuotta jatkuneessa astiakokeessa tutkittiin magnesiumsulfaattina (200 mg Mg/3,9 kg maata), dolomiittikalkki 2:na (1140 mg Mg) tai dolomiittikalkki $1 \mathrm{H}: \mathrm{na}(1320 \mathrm{mg} \mathrm{Mg})$ annetun magnesiumin arvoa raiheinän magnesiumin lähteenä sekä niiden vaikutusta kasveille käyttökelpoiseen magnesiumiin maassa. Maan $\mathrm{pH}\left(\mathrm{CaCl}_{2}\right)$ kohotettiin alkuarvostaan $(4,9)$ kalkkikivijauheella $(12 \mathrm{~g}$ tai $24 \mathrm{~g} \mathrm{kalkkia/3,9} \mathrm{kg} \mathrm{maata)}$ 5,7 :ään tai 6,5 :een. Peltoviljelyyn sovellettuna dolomiittikalkkimäärät ja pienempi kalkkikivijauhemäärä vastaavat $5 \mathrm{t} / \mathrm{ha}$ ja suurempi kalkkikivijauhemäärä $10 \mathrm{t} /$ ha kalkitusta. Magnesiumsulfaatissa tuli noin 90 $\mathrm{kg} / \mathrm{ha}$ magnesiumia.

Kalkkikivijauheena tai dolomiittikalkkeina annettu kalkitus samoin kuin kalkkikivijauhe ja magnesiumsulfaatti yhdessä lisäsivät raiheinän kokonaissatoa keskimäärin $8 \%$.

Ilman kalkkikivijauhetta kasvustojen (8 satoa) keskimääräinen magnesiumpitoisuus oli dolomiittikalkki $1 \mathrm{H}(3,3 \mathrm{mg} / \mathrm{g}$ kuiva-ainetta) käytettäessä merkitsevästi korkeampi kuin dolomiittikalkki 2 :lla $(2,9$ $\mathrm{mg} / \mathrm{g})$ tai magnesiumsulfaatilla $(2,5 \mathrm{mg} / \mathrm{g})$ tuotetuissa sadoissa. Lähellä $\mathrm{pH}\left(\mathrm{CaCl}_{2}\right) 6,5$ kasvustojen keskimääräinen magnesiumpitoisuus $(2,3 \mathrm{mg} / \mathrm{g})$ oli rïppumaton magnesiumin lähteestä.

Magnesiumsulfaattina annetusta magnesiumista oli lähellä $\mathrm{pH}\left(\mathrm{CaCl}_{2}\right) 6,5$ ammoniumasetaattiin $(1 \mathrm{M}$, $\mathrm{pH}$ 7) uuttumattomana noin $20 \%$. Raiheinä näytti käyttävän vähitellen hyväkseen uuttumatonta magnesiumia päätellen siitä, että magnesiumin otto oli toisena vuotena suurempi kuin ensimmäisenä. Ilman kalkitusta magnesiumin otto oli kumpanakin vuotena lähes yhtä suuri. Kokonaisuudessaan magnesiumsulfaatista otettu magnesiummäärä oli kalkitsemattomassa maassa suurempi kuin kalkitussa.

Dolomiittikalkkeina annettu magnesium oli voimakkaasti kalkkikivijauheella kalkitussa maassa lähes kokonaan $(85 \%)$ ammoniumasetaattiin uuttumattomana. Kahden vuoden koejakson aikana raiheinä ei kyennyt käyttämään uuttumatonta magnesiumia hyväkseen. Happamassa maassa dołomiittikalkkien magnesium tuli hitaasti raiheinän käyttöön, sillä ensimmäisen vuoden satojen ottama magnesiummäärä oli noin $35 \%$ koko koeaikana otetusta märästä.

Korkean $\mathrm{pH}\left(\mathrm{CaCl}_{2}\right)$-luvun omaavalle maalle magnesiumlannoitus tulee antaa magnesiumsulfaattina ammoniumasetaattiin uuttumattomien magnesiumyhdisteiden muodostumisesta huolimatta. Dolomiittikalkit taas ovat tehokkaita magnesiumin lähteitä happamissa maissa. 